\title{
Wage and Occupational Differences \\ Between Black and White Men: \\ Labor Market Discrimination in the Rural South*
}

\section{Introduction}

The existence of labor market discrimination based on race is well established. However, study continues into a variety of aspects of discrimination-among them the extent to which it exists in different regions. ${ }^{1}$ Gwartney has estimated the ratio of black to white earnings to be between .83 and .88 for the North and between .68 and .74 for the South [6, 397]. Masters, in a study of earnings differentials between black and white men, found a ratio of .79 for the nonSouth and .69 for the South $[12,349]$.

Although considerable literature has developed concerning earnings differentials, wage discrimination in rural areas is one topic which has received relatively little attention. In an attempt to eliminate this oversight this paper concentrates on the extent of wage differences between black and white men in the rural South attributable to labor market discrimination.

\section{Wage Equation}

The key factor in determining the impact of discrimination on wages is the identification of nonproductivity differentials in wage rates paid to subgroups of the labor force which are the suspected target of discrimination. By estimating a wage function using ordinary least squares the influence of factors not relating to current discrimination can be isolated. The function formulated here utilizes hourly wage rates as the dependent variable and independent variables which measure experience, education and training, health, marital status, and full-time employment.

Experience is entered into the equation through three variables. Age and age squared are included as measures of overall experience recognizing that

"The authors wish to thank Loren C. Scott for helpful comments on an earlier draft of this paper. Financial support was provided by the Employment and Training Administration, U.S. Department of Labor.

1. For a general review of the current status of the literature on racial discrimination see Marshall [11]. Examples of measuring discrimination can be found in Ashenfelter and Rees, Gwartney and Gwartney and Stroup $[1 ; 6 ; 7]$. 
the relationship may not be linear. Both are expected to be positively related to wage rates. Although total experience is important, experience in the job in which an individual is currently employed is equally important. The level of wages increases with length of time on a specific job independent of total experience. Therefore, length of time on present job was included as an independent variable.

Two variables are included to control for human capital differences obtained through formal programs-years of education and training. The training variable, entered in dummy form ( $1=$ training; zero otherwise) includes vocational training, formal on-the-job training, and military training which has a civilian occupational counterpart. Both variables should be positively related to wage rates.

Poor health not only inhibits labor force activity but also affects the level of wages in a negative manner as demonstrated by Luft [10] and Rungeling et al. [14, 135-41]. A dummy variable is included which takes the value of 1 if an individual had a work inhibiting health problem and a value of zero otherwise.

'Two other dummy variables, full time employment and marital status are included in the equation. To the extent that a worker voluntarily chooses parttime employment he often must settle for a wage rate below that paid to fulltime employees performing similar functions. ${ }^{2}$ Thus a positive relationship is expected between this variable and the hourly wage rate. The variable had a value of 1 if the individual normally worked more than 35 hours per week and a value of zero otherwise.

The marital status variable ( 1 if married; zero otherwise) is included because marriage usually creates a pressure upon a head of household to expand his income. In effect, marital status becomes a proxy for a variety of pressures to succeed financially.

The variables included in the equation were chosen not only because they are generally accepted as influencing wages, principally through productivity effects, but also because they are relatively free from the direct effects of labor market discrimination. A variable which is important in wage determination, occupational status, was not included in the equation. The exclusion was necessary because of the almost certain possibility that in the rural South occupational status was directly affected by racial discrimination in the labor market. ${ }^{3}$

Virtually all major studies to date have suffered from the same deficiency; the use of total income and total earnings data rather than wage and salary data. ${ }^{4}$ While the results of these studies show the probable existence of

2. To the extent that blacks are forced into part-time employment more than whites an element of discrimination may be captured in this variable. However, its magnitude is probably quite small.

3. Higgs [8] has established the historical magnitude of occupational segregation by race which existed in the South.

4. For example Gwartney, Masters, and Weiss $[6 ; 12 ; 16]$. 
discrimination, the accuracy of the estimated extent is open to more than the usual number of reservations. This paper utilizes actual wage data collected as a part of a study of 2,537 rural Southern households. ${ }^{5}$ Data were collected on demographic as well as economic characteristics. The regression equation was applied to data on 749 white male and 412 black male workers 16 years of age or older.

Results obtained by least squares analysis are shown in Table I. In general the results conform to expectations, where variables are significant, with the major exception of age squared. One possible explanation for this exception is that although age is positively associated with wage level, the highly physical nature of many of the jobs held by those in the sample is such that at the upper ends of the age spectrum the association between age and wage rates becomes negative. Another possibility is that advanced age may be serving as a proxy for the relatively lower quality of education received by older men in the sample.

\section{Labor Market Discrimination}

If the mean wage rate for blacks is compared directly with that for whites, the results would appear to indicate substantial labor market discrimination. Such results may be misleading because nondiscriminatory differences in wage rates are not excluded. One method of measuring the extent of discrimination is to estimate the relative wages which blacks would have if they have productivity characteristics similar to whites. This can be accomplished by substituting the mean white values for each variable into the wage equation of blacks and comparing the results with the mean earnings for whites. ${ }^{6}$

The adjusted ratio becomes the ratio of the sum of the coefficients of the black wage equation applied to mean values of the variables for whites and a similar computation involving the white equation to obtain the white mean. If no discrimination is present, the adjusted ratio would equal one. Deviations of the ratio from unity can be interpreted as a relative measure of discrimination in wages rates. ${ }^{7}$

5. The sample was selected by stratifying rural southern counties by race and selecting for interview a 10 percent simple random sample from one county randomly selected from each strata. The counties selected were: Dodge County in central Georgia with a population which is 25 percent black; Natchitoches Parish, in central Louisiana with a population which is 37 percent black; and Sunflower County in west central Mississippi with a population which is 60 percent black. The term rural as used in this study conforms to the definition developed by the United States Department of Labor. For a detailed discussion of the sample see Rungeling et al. [14, 11-12].

6. For an application of similar methodology to the study of discrimination as well as other economic differences in earnings see Link and Ratledge, Luft, and Weiss $[9 ; 10 ; 16]$.

7. The adjusted ratio of black wages to white wages equals

$$
\sum R_{b 1} M_{t o i} / \sum R_{t o R I} M_{t w t}
$$

where $R_{i}$ represents the $i$ th regression coefficient, $M_{i}$ represents the mean value of the $i$ th variable and $b$ and $w$ represent race. 
Table I. Results of Regression Equations*

\begin{tabular}{|c|c|c|c|c|}
\hline \multirow[t]{2}{*}{ Variable } & \multicolumn{2}{|c|}{ Black } & \multicolumn{2}{|c|}{ White } \\
\hline & Coefficient & Mean & Coefficient & Mean \\
\hline Age & $(4.34)$ & 37.7 & $(4.30)$ & 40.2 \\
\hline Age Squared & 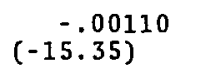 & 1638.1 & $\left(-\frac{-.00137}{-12)}\right.$ & 1824.9 \\
\hline Education & $\begin{array}{l}.13959 \\
(9.19)\end{array}$ & 8.2 & 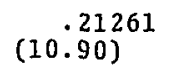 & 10.9 \\
\hline Years At Present Job & $\begin{array}{l}.00190 \\
(.02)\end{array}$ & 7.4 & $\begin{array}{c}.08894 \\
(5.56)\end{array}$ & 7.8 \\
\hline Health Problem & $\begin{array}{l}.12376 \\
(.07)\end{array}$ & .08 & $\begin{array}{l}-.53360 \\
(-2.08)\end{array}$ & .06 \\
\hline Trained & $\begin{array}{l}.55722 \\
(2.87)\end{array}$ & .07 & $\begin{array}{l}.13805 \\
(.82)\end{array}$ & .17 \\
\hline Married & $(1.20)$ & .78 & $(3.7785)$ & .84 \\
\hline Fu11-time & $\begin{array}{l}-.05790 \\
(-.38)\end{array}$ & .85 & $\begin{array}{l}-.21889 \\
(-.93)\end{array}$ & .91 \\
\hline Constant & -1.24616 & & -2.32573 & \\
\hline $\mathrm{R}^{2}$ & .25 & & .27 & \\
\hline F of Equation & 16.56 & & 34.30 & \\
\hline $\mathrm{N}$ & 412 & & 749 & \\
\hline Mean Wage & 2.27 & & 3.73 & \\
\hline
\end{tabular}

* $t$-values are in parentheses.

The simple wage ratio (unadjusted) indicates that on average there is a 39 percent differential between the wages of black and white men in this study. When productivity differences due to differences in education, training, experience, and health are held constant the wage differential falls to 26 percent (\$.96 per hour in dollar terms). ${ }^{8}$ The results indicate that although wage

8. The relationship between years of education and wages may be affected by qualitative differences in black and white schooling making an unambiguous interpretation of the education variable difficult and possibly biasing the adjusted wage ratio. Previous studies such as those by Masters [12] and Weiss [16] used findings of the Coleman Report or the Armed Forces Qualification Test to adjust for qualitative differences in educational attainment. To ascertain the effect which such differences might have on the findings of this study, the education variable in the black equation was adjusted downward. The adjustment factor was adapted from the differences in black and white educational attainment in the South cited in the Coleman Report [3, 272-77]. When the equation was re-estimated the adjusted wage ratio was .82 as compared to the previous ratio of 74 .

The results seem to indicate that qualitative differences in educational attainment account for 
discrimination between black and white men in the rural South is less than casual observation would indicate it is still substantial.

\section{Occupation Segregation}

A major difficulty with utilizing the adjusted ratio as a measure of wage discrimination lies in the specification of the earnings equation. There are factors not included in the wage equation which could cause wage differentials resulting from labor market discrimination. The most important of these is occupational status. Substantial discrimination which limits the occupational choice of black or white men could account for part or even a majority of the observed wage differences. To test the proposition that occupational segregation does exist between black and white men in the rural South a model to measure the effect of various factors on occupation of employment was utilized. In addition to a variable measuring racial probabilities ( 1 if black; zero if white), independent variables measuring the effect on occupational status of age, education and training, and health were included.

Because the occupational variables are dichotomous dependent variables (taking a value of 1 if the individual is in a given occupation or zero otherwise) the ordinary least squares (OLS) regression technique of estimating occupation of employment is inappropriate since such a dependent variable would introduce heteroskedasticity in the error term. As a result, the variances of the coefficients in an OLS equation would be biased in a direction that may lead to rejection of the existence of discrimination in some occupations when in fact that race coefficient may be statistically significant. ${ }^{9}$ To correct for this problem the probit technique developed by Finney [4] was utilized to estimate the occupation equations.

An equation was estimated for each of twelve occupational categories. ${ }^{10}$ The statistical significance and sign of the race variable will indicate if racial segregation exists in a given occupation and in what direction. The coefficient and $t$-value for the race variable as well as the sample size and mean wage for each occupation are shown in Table II. A negative sign for the coefficient indicates a "white" occupation and a positive sign a "black" occupation.

\footnotetext{
at least part of the previous unexplained wage differential. However, the data from the Coleman report is over a decade old and it does not pertain specifically to the rural South. Further, the occupational structure in the study area is such that the qualitative differences estimated by the Coleman Report should have a minimal effect on wages. As a result, the qualitative adjustment of the education variable in this study does not enhance the estimation of wage differences resulting from discrimination.

9. In addition, the resulting estimate of the conditional probability of employment in a given occupation is not constrained to fall within the zero to one range. See Goldberger $[5,248-51]$.

10. The men in the sample were allocated among fourteen occupational categories. Two categories, Food and Beverage and Domestic Service were eliminated from the analysis because each contained too few observations to allow meaningful equation estimation.
} 
Table II. Estimated Employment Probabilities

\begin{tabular}{|c|c|c|c|c|}
\hline Occupation & $\begin{array}{c}\text { Sample } \\
\text { Size }\end{array}$ & $\begin{array}{l}\text { Mean } \\
\text { Wage }\end{array}$ & Coefficient & $t$-value \\
\hline Professional & 72 & $\$ 4.50$ & .18767 & 1.16 \\
\hline Administrative & 101 & 4.48 & -.76385 & -4.26 \\
\hline $\begin{array}{l}\text { Assembly Line Manu- } \\
\text { facturing }\end{array}$ & 103 & 3.94 & -.34306 & -2.75 \\
\hline Construction & 132 & 3.48 & -.17421 & -1.58 \\
\hline Technical & 71 & 3.44 & -.44894 & -2.96 \\
\hline Sales & 66 & 3.18 & -.58728 & -3.47 \\
\hline $\begin{array}{l}\text { New Material } \\
\text { Manufacturing }\end{array}$ & 54 & 3.11 & .26037 & 1.86 \\
\hline $\begin{array}{l}\text { Durables Manufactu- } \\
\text { ring }\end{array}$ & 121 & 3.05 & -.23783 & -2.07 \\
\hline Service & 59 & 2.78 & .42299 & 2.96 \\
\hline Transportation & 105 & 2.76 & .03386 & 0.29 \\
\hline Packaging & 44 & 2.61 & .40995 & 2.67 \\
\hline Farming & 205 & 2.16 & .49328 & 4.90 \\
\hline
\end{tabular}

In all, eight occupational categories were found to exhibit racial segregation. Clearly the pattern of segregation is detrimental to black workers. Five of the top six occupational categories, in terms of mean wages, had negative signs and four of the six were significant. The top category, professional, exhibited no significant difference by race. This is accounted for by the relatively large number of teachers in this category of which a substantial percentage were black. The last four ranked categories all had positive signs and three were significant.

\section{Implications}

The results of the analysis indicate the existence of a substantial unexplained wage differential than can reasonably be attributed to racial discrimination. The extent of this differential (26 percent) is in the same general magnitude as that found by Gwartney [6] and Masters [12] for the South as a whole leading to the conclusion that although wage discrimination is substantial it is no worse in the rural South than in the entire South and probably the nation as a whole.

Following the analysis of Bergmann [2], it could be assumed that occupa- 
tional segregation and hence segmentation would cause a crowding of one market or a shortage in another, which would lead to a difference in wages. The results of this analysis strongly support the existence in the rural South of a labor market which is occupationally segmented by race and can inferentially support the crowding hypothesis.

The implications of occupational segmentation go beyond just wage discrimination. Blacks predominate in those occupations which are most subject to employment irregularities. This is illustrated in part in the sample by a mean weeks worked in 1973 for blacks of 45 as compared to 50 for whites. Moreover, within the "black" occupations, 89 percent of the white workers worked 48 weeks or more during 1973 compared to only 71 percent of the black workers. The economic ramifications are greater than just wage differentials.

Those occupations which are classified as "black" are also among those of lowest status, particularly service and farming. Moreover, they are among the lowest in terms of short-run growth potential in the rural South. ${ }^{11}$ Employment opportunities are restricted for all young workers in the rural South but the two factors mentioned above indicate the problem is greatest for young blacks. This holds important implications for future migration patterns from the rural South.

Occupational segmentation and wage discrimination may also account for the relatively lower labor force participation rates found for black men in the rural South. ${ }^{12}$

The main recommendation to be drawn from the results is rigorous enforcement of the E.E.O.C. regulations as they apply to both wages and employment. Strict application of Federal laws that apply to racial discrimination should tend to reduce the measured wage discrimination and also have an effect on occupational segregation.

One further point should be mentioned regarding wage differences. The results found here indicate that black men in general possess less of the "productivity factors," mainly education and training, than do white men. This fact may itself be the result of past or present discrimination in areas

11. For a discussion of the occupational status determination and the growth prospect for various occupations in the rural South see Rungeling et al. [14, 76-83].

12. The difference in labor force participation among workers in the rural South is discussed in Scott, Smith and Rungeling [15]. 
other than the labor market and anti-discrimination policy in the rural South must take this fact into consideration.

Lewis H. Smith

University of Mississippi

Vernon M. Briggs, Jr.

University of Texas

Brian Rungeling

University of Mississippi

James O. Smith, Jr.

University of Mississippi

\section{References}

1. Ashenfelter, Orley and Rees, Albert, eds. Discrimination in Labor Markets. Princeton: Princeton University Press, 1973.

2. Bergmann, Barbara R., "The Effect on White Incomes of Discrimination in Employment," Journal of Political Economy, March/April, 1971, 294-313.

3. Coleman, J. S. et al. Equality of Educational Opportunity. U.S. Department of Health, Education and Welfare, National Center for Education Statistics, 1966.

4. Finney, D. J. Probit Analysis. Cambridge: The University Press, 1971.

5. Goldberger, Arthur S. Econometric Theory. New York: John Wiley and Sons, 1964.

6. Gwartney, James, "Discrimination and Income Differentials." American Economic Reviewv, June 1970, 396-408.

7. Sex." Southern Economic Journal, April, 1973, 575-87.

8. Higgs, Robert, "Firm Specific Evidence on Racial Wage Differences and Workforce Segregation." American Economic Review, March 1977, 236-45.

9. Link, Charles R. and Edward C. Ratledge, "The Influence of the Quantity and Quality of Education on Black-White Earnings Differentials: Some New Evidence." Review of Economics and Statistics, August 1975, 346-50.

10. Luft, H. S., "The Impact of Poor Health on Earnings." Review of Economics and Statistics, February 1975, 43-57.

11. Marshall, Ray, "The Economics of Discrimination: A Survey." Journal of Economic Literature, September 1974, 849-72.

12. Masters, Stanley, "The Effect of Educational Differences and Labor Market Discrimination on the Relative Earnings of Black Males." Journal of Human Resources, Summer, 1974, 342-60.

13. Oaxaca, Ronald, "Male-Female Wage Differentials in Urban Labor Markets." International Economic Reviewv, October 1973, 693-709.

14. Rungeling, Brian, Lewis H. Smith, Vernon M. Briggs, and John F. Adams, Employment, Income and Welfare in the Rural South. New York: Praeger, 1977.

15. Scott, Loren C., Lewis H. Smith, and Brian Rungeling, "Labor Force Participation in Southern Rural Labor Markets." American Journal of Agricultural Economics, May 1977, 266-74.

16. Weiss, Randall D., "The Effect of Education on the Earnings of Blacks and Whites." Review of Economics and Statistics, May, 1970, 150-59. 